\title{
Thermal curing of PBI membranes for high temperature PEM fuel cells
}

\author{
Aili, David; Cleemann, Lars N.; Li, Qingfeng; Jensen, Jens Oluf; Christensen, Erik; Bjerrum, Niels J.
}

Published in:

Journal of Materials Chemistry

Link to article, DOI:

10.1039/c2jm14774b

Publication date:

2012

Document Version

Publisher's PDF, also known as Version of record

Link back to DTU Orbit

Citation (APA):

Aili, D., Cleemann, L. N., Li, Q., Jensen, J. O., Christensen, E., \& Bjerrum, N. J. (2012). Thermal curing of PBI membranes for high temperature PEM fuel cells. Journal of Materials Chemistry, 22(12), 5444-5453.

https://doi.org/10.1039/c2jm14774b

\section{General rights}

Copyright and moral rights for the publications made accessible in the public portal are retained by the authors and/or other copyright owners and it is a condition of accessing publications that users recognise and abide by the legal requirements associated with these rights.

- Users may download and print one copy of any publication from the public portal for the purpose of private study or research.

- You may not further distribute the material or use it for any profit-making activity or commercial gain

- You may freely distribute the URL identifying the publication in the public portal 


\title{
Materials Chemistry
}

Cite this: J. Mater. Chem., 2012, 22, 5444

www.rsc.org/materials

PAPER

\section{Thermal curing of PBI membranes for high temperature PEM fuel cells}

\author{
David Aili, Lars N. Cleemann, Qingfeng Li, “ Jens Oluf Jensen, Erik Christensen and Niels J. Bjerrum
}

Received 25th September 2011, Accepted 27th December 2011

DOI: $10.1039 / \mathrm{c} 2 \mathrm{jm} 14774 \mathrm{~b}$

Phosphoric acid doped polybenzimidazole (PBI) has emerged as one of the most promising electrolyte materials for proton exchange membrane (PEM) fuel cells operating under anhydrous conditions at temperatures of up to $200{ }^{\circ} \mathrm{C}$. The limited long-term durability of the membrane electrode assemblies (MEAs) is currently hampering the commercial viability of the technology. In the present study, thermoset PBI membranes were prepared by curing the membranes under inert atmosphere at temperatures of up to $350{ }^{\circ} \mathrm{C}$ prior to the acid doping. The systematic membrane characterizations with respect to solubility, phosphoric acid doping, radical-oxidative resistance and mechanical strength indicated that the PBI membranes were irreversibly cured by the thermal treatment. After curing, the PBI membranes demonstrated features that are fundamental characteristics of a thermoset resin including complete insolubility, high resistance to swelling and improved mechanical toughness.

Additionally, the thermal treatment was found to increase the degree of crystallinity of the membranes. The improved physicochemical characteristics of the membranes after curing were further illustrated by a dramatically improved long-term durability of the corresponding fuel cell MEAs. During continuous operation for $1800 \mathrm{~h}$ at $160{ }^{\circ} \mathrm{C}$ and $600 \mathrm{~mA} \mathrm{~cm}^{-2}$, the average cell voltage decay rate of the MEA based on the cured membrane was $43 \mu \mathrm{Vh}^{-1}$. This should be compared with an average cell voltage decay rate of $308 \mu \mathrm{V} \mathrm{h}^{-1}$ which was recorded for the MEA based on its non-cured counterpart.

\section{Introduction}

During the past few decades, phosphoric acid (PA) doped poly [2,2' (m-phenylene)-5,5'bibenzimidazole] (PBI, Fig. 1) has evolved as one of the most promising electrolyte materials for proton exchange membrane (PEM) fuel cells operating under anhydrous conditions at temperatures of up to $200^{\circ}$ C. ${ }^{1,2}$ Above this temperature range, only inorganic oxyacid salts, e.g. hydrogen sulfates and phosphates, might be possible candidate electrolyte materials, as recently reviewed. ${ }^{3}$

As a fully aromatic heterocyclic polymer, PBI possesses a very high glass transition temperature $\left(T_{\mathrm{g}}\right)$ of $425-436^{\circ} \mathrm{C}$ and excellent thermal and chemical stability..$^{4-7} \mathrm{PBI}$ is also characterized by its mechanical toughness. For example, among all known

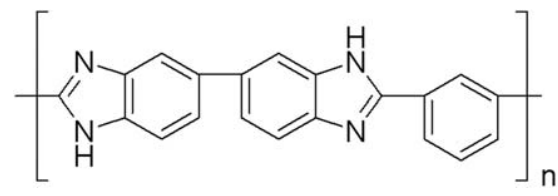

Fig. 1 Chemical structure of PBI.

Technical University of Denmark, Department of Chemistry, Kemitorvet 207, Kgs. Lyngby, Denmark. E-mail: lqf@kemi.dtu.dk; Fax: +45 4588 3136; Tel: +4545252318 engineering plastics it has the highest reported compression strength.

The high $T_{\mathrm{g}}$ of PBI excludes the conventional polymer processing techniques such as thermoforming, moulding or melt extrusion. PBI only exhibits sufficient solubility in a few organic solvents which can be used for fiber extrusion and membrane casting. The commercially available PBI (Celazole ${ }^{\circledR}$, Celanese) has a low to medium linear molecular weight ranging from about $23-37 \mathrm{kDa}$ corresponding to an intrinsic viscosity of 0.55 $0.80 \mathrm{dL} \mathrm{g}^{-1}{ }^{8} \mathrm{PBI}$ in the lower region of this molecular weight range gives rather poor membranes in terms of mechanical stability and oxidative resistance, and fractionation seems necessary before membrane casting in order to concentrate the high molecular weight fraction of the polymer batch. ${ }^{9}$

The proton conductivity of the PA doped PBI membrane is highly dependent on the acid doping level (DL) of the membrane, which is defined as the number of PA molecules per repeating unit of the polymer. For example, under anhydrous conditions at $180{ }^{\circ} \mathrm{C}$ the conductivity increases from about $0.03 \mathrm{~S} \mathrm{~cm}^{-1}$ to $0.25 \mathrm{~S} \mathrm{~cm}^{-1}$ when the doping level is increased from 6 to $32 .^{10,11}$ However, doping with phosphoric acid dramatically lowered the $T_{\mathrm{g}}$ of the membrane and therefore the yield stress and modulus of the materials. ${ }^{12}$ The mechanical characteristics of PBI membranes at high doping levels can thus be improved by increasing the linear average molecular weight of the polymer ${ }^{12}$ or by covalent ${ }^{10,13-16}$ or ionic ${ }^{17-20}$ crosslinking. 
After heat treatment at $500{ }^{\circ} \mathrm{C}$, Vogel and $\mathrm{Marvel}^{5}$ observed that PBI becomes completely insoluble in all standard solvents. Apart from the linear chain growth through continued polycondensation, it was suggested that crosslinking had occurred through free radical reactions. Gillham ${ }^{22}$ further investigated the thermo-mechanical properties of PBI and confirmed that PBI changes from a thermoplastic polymer to a thermoset resin at about $450{ }^{\circ} \mathrm{C}$. Based on spectroscopic evidence it was also confirmed that crosslinking had occurred, ${ }^{23}$ as also discussed by Levine. ${ }^{21}$ This was further illustrated at a macroscopic scale by Hwang et al. ${ }^{24}$ who showed that heat treatment of spun ABPBI fibres at temperatures up to $540{ }^{\circ} \mathrm{C}$ increased the Young's modulus by $153 \%$ and the engineering tensile strength by $63 \%$. At the same time the elongation at break was considerably decreased.

Based on extensive FTIR characterization, on the other hand, the early stages of the PBI thermo-oxidative degradation were analyzed by Musto et al. ${ }^{25}$ who also observed that the PBI membranes that had been heat treated under air at even lower temperatures $\left(350^{\circ} \mathrm{C}\right)$ for 30 minutes were practically insoluble in DMAc. Shulman and Lochte ${ }^{26}$ proposed a mechanism for the thermal oxidation of PBI at temperatures above $450{ }^{\circ} \mathrm{C}$. It involved chain scission accompanied by crosslinking reactions, either by amide interchange or by benzene-biphenyl type coupling. The weakest links in the PBI backbone in a thermooxidative environment were obviously the nitrogen containing heterocyclics and the adjacent benzenoid rings. ${ }^{27,28}$ Later, Linkous $^{29}$ evaluated thermo-oxidatively crosslinked PBI as a potential electrolyte material for PEM steam electrolyzers.

In the present work, the post-heat treatment technique was investigated to process the preformed PBI membranes for high temperature PEM fuel cells.

\section{Experimental}

\section{Membrane preparation}

PBI with average molecular weights ranging from 23 to $64 \mathrm{kDa}$ was supplied by Danish Power Systems ApS. The weight averaged molecular weights were determined by viscometry measurement in concentrated sulfuric acid using the empirical Mark-Houwink constants $K=1.94 \times 10^{-4} \mathrm{dL} \mathrm{g}^{-1}$ and $\alpha=$ $0.791 .^{30}$ The PBI was supplied either as powders or as membranes that had been solution cast from DMAc through solvent evaporation. The PBI powders were dissolved in DMAc to give $5 \mathrm{wt} \%$ solutions after filtering. PBI membranes were subsequently solution cast from the DMAc solution on glass substrates and dried at temperatures of $60-120{ }^{\circ} \mathrm{C}$ for a duration of up to 20 hours. The membrane thicknesses prior to acid doping varied between 20 and $80 \mu \mathrm{m}$.

The heat treatments were conducted in a quartz lined tube furnace at temperatures ranging from 200 to $500{ }^{\circ} \mathrm{C}$ under air or argon atmosphere. For the membranes that were heat treated under argon atmosphere, the furnace was repeatedly evacuated and filled with argon at room temperature before the heat treatment procedure was started. During the heat treatment, argon was continuously purged through the furnace at a flow rate of about $100-200 \mathrm{~mL} \mathrm{~min}^{-1}$.

Since the eventual chemical or physical effects on the membrane were assumed to be dependent on the thermal curing duration, two different standard curing procedures were established for the systematic membrane characterization. During the short thermal curing procedure, the sample was heated up to $350{ }^{\circ} \mathrm{C}$ in about 10 minutes. When the furnace interior reached the target temperature, the membrane sample was treated isothermally for about 1 minute before the power was switched off and the furnace was allowed to cool down to room temperature, which took about 1.5-2 h. During the long thermal curing procedure, the sample was treated isothermally at $350{ }^{\circ} \mathrm{C}$ for $16 \mathrm{~h}$. The membranes obtained after the short and long curing procedures are hereafter referred to as $\mathrm{xx}-\mathrm{Sh}-\mathrm{C}$ and $\mathrm{xx}-\mathrm{Lo}-\mathrm{C}$, respectively. The non-cured reference membranes are hereafter referred to as $\mathrm{xx}$-Ref. In this context, $\mathrm{xx}$ corresponds to the linear average molecular weight of PBI in $\mathrm{kDa}$.

Acid doping was achieved by submerging the membranes in $85 \mathrm{wt} \% \mathrm{H}_{3} \mathrm{PO}_{4}$ at temperatures ranging from 20 to $100{ }^{\circ} \mathrm{C}$. The acid doping levels were calculated on the dry polymer basis and the dry weights after doping (dried at $150{ }^{\circ} \mathrm{C}$ until a constant weight was obtained).

\section{Membrane characterization}

Attenuated Total Reflectance Fourier Transform Infrared (ATR-FTIR) spectroscopy was conducted using a Perkin Elmer Spectrum One FTIR spectrometer equipped with a universal ATR sampling accessory. The membrane samples were pre-dried at $200{ }^{\circ} \mathrm{C}$ for $4 \mathrm{~h}$ before the spectra were recorded.

The TGA/DTA data were acquired using a Netzsch STA 409 PC. The samples were pre-dried at $250{ }^{\circ} \mathrm{C}$ in vacuo for $12 \mathrm{~h}$ in the chamber and thereafter cooled down to room temperature. The thermograms were recorded at a heating rate of $10{ }^{\circ} \mathrm{C} \min ^{-1}$ and argon was used as the purge gas.

For the Fenton test, the membrane samples ( $40 \mu \mathrm{m}$ thick) were submerged in a $3 \mathrm{wt} \% \mathrm{H}_{2} \mathrm{O}_{2}$ (Merck) aqueous solution containing 4 ppm $\mathrm{Fe}(\mathrm{II})$ (added as $\left.\left(\mathrm{NH}_{4}\right)_{2} \mathrm{Fe}\left(\mathrm{SO}_{4}\right)_{2} \cdot 6 \mathrm{H}_{2} \mathrm{O}\right)$ at $68^{\circ} \mathrm{C}$. After certain durations (maximum $20 \mathrm{~h}$ ), the membrane samples were collected, rinsed with demineralized water and dried at $120{ }^{\circ} \mathrm{C}$ for at least $5 \mathrm{~h}$. The dry weights were recorded and the membrane samples were submerged in freshly prepared Fenton solution for continuation of the test. The presented results are the data from single measurements and the experimental errors have thus not been evaluated.

X-Ray diffraction (WAXD) data were recorded on a Huber D670 diffractometer equipped with a $\mathrm{Cu}-\mathrm{K} \alpha \mathrm{X}$-ray source.

Stress-strain curves were recorded under ambient conditions using an initial sample length of $30 \mathrm{~mm}$ and a grip separation rate of $10.00 \mathrm{~mm} \mathrm{~min}^{-1}$. The equipment used was a modified universal materials testing machine (Testometric Micro 350).

In-plane proton conductivity was measured at temperatures ranging from 110 to $180{ }^{\circ} \mathrm{C}$ under anhydrous conditions. The membrane samples were pre-conditioned at $180{ }^{\circ} \mathrm{C}$ for about $16 \mathrm{~h}$ before the sample dimensions were determined. The temperature was then systematically lowered and the conductivity was recorded at intervals of $10{ }^{\circ} \mathrm{C}$. The measurements were carried out using a four-probe conductivity cell. A symmetric square wave current was supplied through platinum foils in the $5-10 \mathrm{kHz}$ frequency range. The voltage drop was measured via platinum probes fixed $1.0 \mathrm{~cm}$ apart. 


\section{MEA preparation and fuel cell testing}

A platinum catalyst $(56.2 \mathrm{wt} \% \mathrm{Pt})$ supported on carbon black was used to prepare catalyst layers by spraying the catalyst dispersion onto carbon based non-woven gas diffusion layers, which had been pre-coated with a micro-porous carbon layer. PBI was used as the catalyst binder $\left(0.1 \mathrm{mg} \mathrm{cm}^{-2}\right)$, which after PA impregnation functioned as a proton conducting phase in the electrode. The Pt loading of the final electrodes was $0.58 \mathrm{mg} \mathrm{cm}^{-2}$ at the cathode and $0.29 \mathrm{mg} \mathrm{cm}^{-2}$ at the anode.

The MEAs were prepared by Danish Power Systems ApS by sandwiching the PA doped PBI membranes between two pieces of gas diffusion electrodes and hot-pressed at $200{ }^{\circ} \mathrm{C}$ under a pressure of about $4 \mathrm{MPa}$ for $3 \mathrm{~min}$.

The size of the active electrode area of the MEAs was $10 \mathrm{~cm}^{2}$. The MEAs were tested in single cells consisting of two graphite plates with simple parallel gas channels. Two end plates made of aluminium with attached heaters were used to clamp the graphite plates and a separate silver coated current collector was used to collect the current from the cell.

For the fuel cell tests, dry hydrogen and air were used without pre-humidification at flow rates of 110 and $450 \mathrm{~mL} \mathrm{~min}{ }^{-1}$, respectively. Even at the maximum current densities, the gas flow rates were much higher than the consumption. In this way the fuel cell tests were performed in order to evaluate the materials but not to optimize the cell operation.

\section{Results and discussion}

\section{ATR-FTIR}

After heat treatment of the PBI membrane for $16 \mathrm{~h}$ under an oxygen containing atmosphere at temperatures of above $300{ }^{\circ} \mathrm{C}$, the appearance of the FTIR spectrum was dramatically changed.

As shown in Fig. 2A, the most pronounced difference was observed in the $1000-1800 \mathrm{~cm}^{-1}$ region of the spectrum, which is mainly assigned to different vibration and breathing modes of the aromatic backbone. For example, the intense absorption bands centred around $1540 \mathrm{~cm}^{-1}$ and at about $1640 \mathrm{~cm}^{-1}$ have previously been assigned to stretching modes of $\mathrm{C}=\mathrm{C}$ and $\mathrm{C}=\mathrm{N}$ bonds in the aromatic backbone, respectively. ${ }^{31}$ As previously reported, two new absorption bands at about $2230 \mathrm{~cm}^{-1}$ and $1715 \mathrm{~cm}^{-1}$ were observed in the FTIR spectrum of the PBI membrane that had been heat treated under air at $350{ }^{\circ} \mathrm{C} .{ }^{25}$ The $2230 \mathrm{~cm}^{-1}$ absorption band was assigned to stretching vibrations of aromatic nitrile groups originating from the imidazole moieties, whereas the absorption band at $1715 \mathrm{~cm}^{-1}$ was assigned to various carbonyl containing functionalities that were formed due to the extensive thermal oxidation of the polymer. In the radical induced oxidation of PBI membranes (Fenton test) a considerable intensity strengthening of the absorbance peak at around $1640 \mathrm{~cm}^{-1}$ was observed, indicating the formation of carbonyl functionalities. ${ }^{31} \mathrm{~A}$ new wide absorption band was also observed at around $1100 \mathrm{~cm}^{-1}$ that was assigned to hydroxyl functionalities.

The literature data of oxidized PBI were in good agreement with the changed appearance of the FTIR spectrum of the PBI membrane after the heat treatment under air at $350{ }^{\circ} \mathrm{C}$ in the present study. Conclusively, the general broadening of the absorbance bands in the $1000-1800 \mathrm{~cm}^{-1}$ region of the spectrum
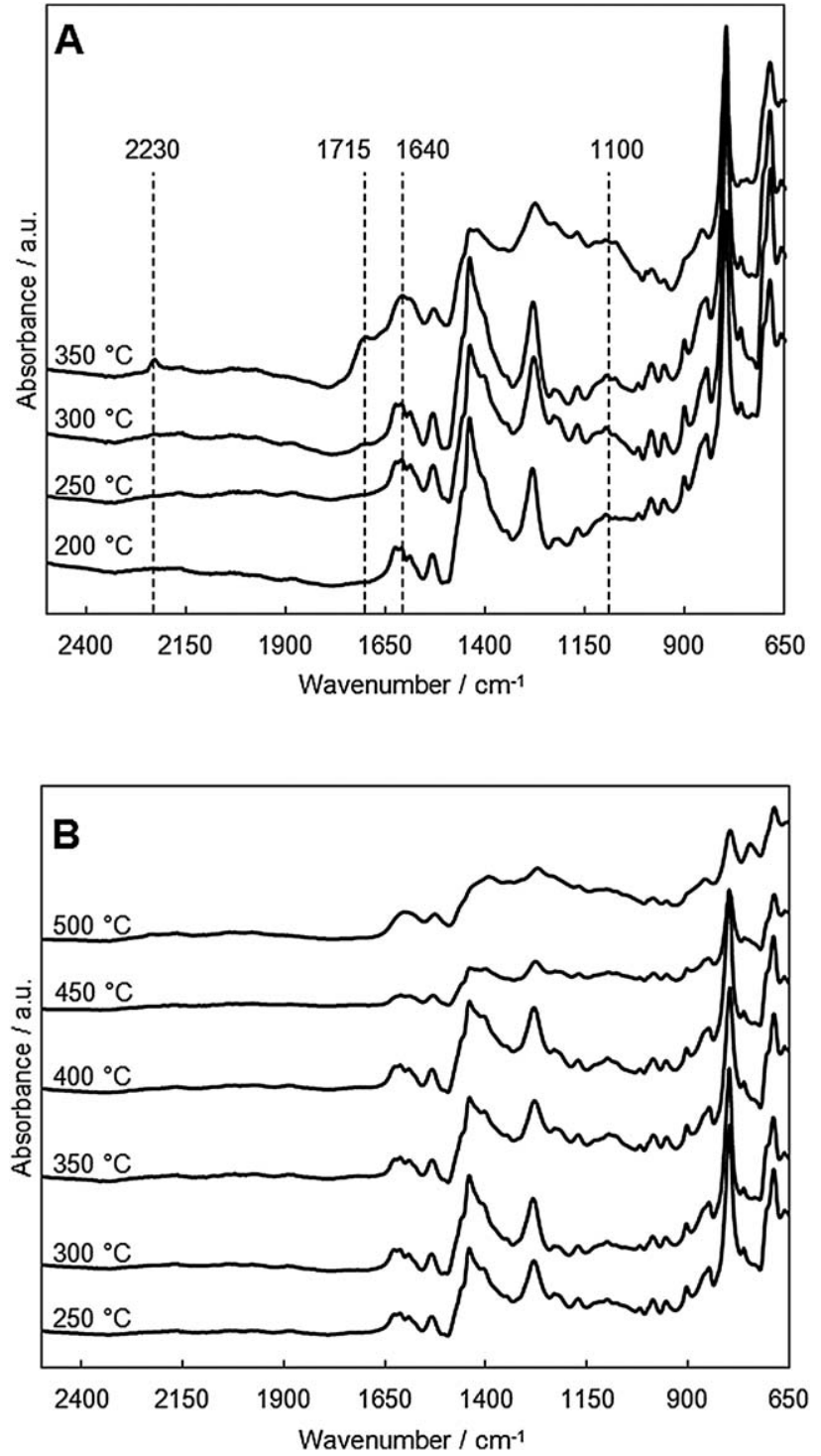

Fig. 2 ATR-FTIR spectra of the PBI membranes that had been treated at different temperatures for $16 \mathrm{~h}$ under air (A) or argon (B) atmosphere. The $2500-4000 \mathrm{~cm}^{-1}$ regions of the spectra are omitted for clarification.

indicates severe oxidation of the polymer backbone. The extensive oxidation should ultimately result in polymer chain scission and thus a dramatic decrease of the linear molecular weight, as also confirmed for thermally oxidized $\mathrm{PBI}^{25}$ or PBI membranes that had been subjected to radical induced oxidation in the Fenton test. ${ }^{31,32}$

On the other hand, the PBI membranes that had been heat treated under inert argon atmosphere showed considerably better stability at higher temperatures in general, as shown in Fig. 2B. Under a continuous argon flow the PBI membranes could be heat treated at temperatures up to $400{ }^{\circ} \mathrm{C}$ for at least $16 \mathrm{~h}$ without affecting the visual appearance of their FTIR spectra.

\section{TGA/DTA}

Thermal analysis can be used to determine crosslinking temperatures of polymers since the crosslinking reactions are generally exothermic to some extent. For example, Han et al. ${ }^{16}$ used DSC 
to determine the crosslinking temperature of PBI and an epoxy resin, which was identified as a small exotherm at about $160^{\circ} \mathrm{C}$.

Thermogravimetric analysis (TGA) and differential thermal analysis (DTA) data of the non-cured reference membrane (48Ref) and the membrane that had been pre-cured at $350{ }^{\circ} \mathrm{C}$ for $16 \mathrm{~h}$ under argon (48-Lo-C) are shown in Fig. 3. The samples were pre-dried in vacuo at $250{ }^{\circ} \mathrm{C}$ for $16 \mathrm{~h}$ in the chamber before the measurement was started in order to completely evaporate the solvent residuals and absorbed moisture.

The non-cured reference membrane (48-Ref) showed a weight loss with an onset temperature at about $350{ }^{\circ} \mathrm{C}$, which was also the standard curing temperature of the PBI membranes in the present study. The total weight loss in the $350-450{ }^{\circ} \mathrm{C}$ temperature range was about $0.7 \%$. On the other hand, this weight loss was not observed in the thermogram of the membrane that had been pre-cured at $350{ }^{\circ} \mathrm{C}(48-\mathrm{Lo}-\mathrm{C})$. The onset of weight loss of the pre-cured membrane 48-Lo-C did not start until the temperature reached about $430{ }^{\circ} \mathrm{C}$. The small weight loss at $350{ }^{\circ} \mathrm{C}$ of the non-cured membrane 48 -Ref could thus be associated with crosslinking reactions giving off volatile species as PBI changes from a thermoplastic polymer to a thermoset resin.

An exotherm was also observed in this temperature range, which further indicates that chemical reactions such as crosslinking were taking place. However, although no obvious weight loss was recorded in this temperature range, the exotherm was also observed in the DTA of the membrane that had been cured at $350{ }^{\circ} \mathrm{C}$ for $16 \mathrm{~h}$ (48-Lo-C) before the experiment. The exotherm in the DTA of the 48-Lo-C membrane could indicate that further crosslinking reactions were taking place when the membrane was re-heated to $350{ }^{\circ} \mathrm{C}$. However, the continuation of the thermal curing process obviously did not result in any volatile species since no weight loss was recorded.

\section{Solubility}

Previous studies on heat treatment of PBI at temperatures of $350-500{ }^{\circ} \mathrm{C}$ have shown that the thermal treatment results in an almost completely insoluble material. ${ }^{5,25}$ Based on thermo-

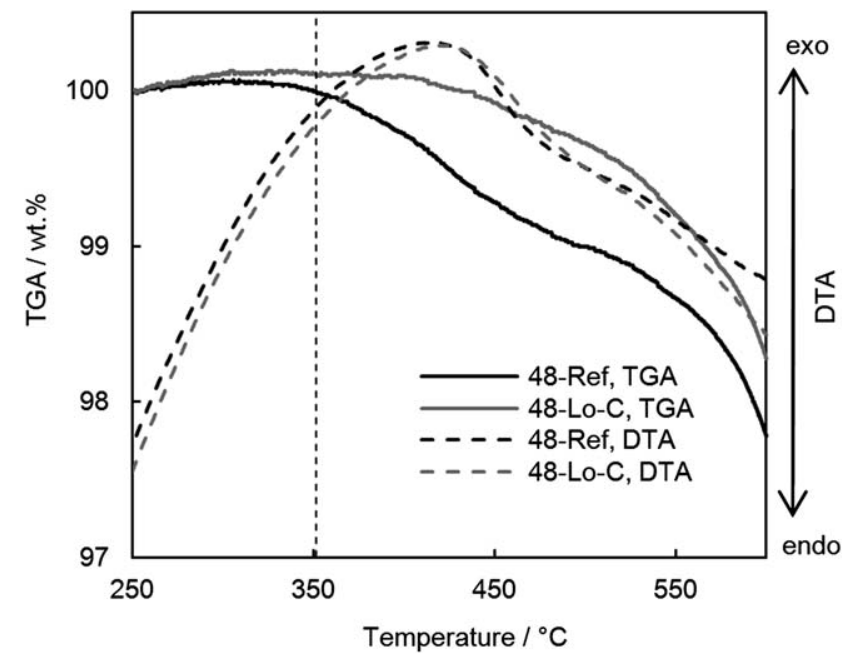

Fig. 3 TGA and DTA data of the non-cured reference membrane (48Ref) and of the membrane that had been pre-cured at $350{ }^{\circ} \mathrm{C}$ for $16 \mathrm{~h}$ under argon (48-Lo-C). The standard curing temperature is highlighted by a dashed line at $350{ }^{\circ} \mathrm{C}$. mechanical measurements ${ }^{22}$ and spectroscopic evidence ${ }^{21,23}$ the complete insolubility was assigned to a dramatic increase of the molecular weight through crosslinking.

The complete insolubility of PBI after thermal treatment at $350{ }^{\circ} \mathrm{C}$ was also confirmed in the present study, as shown in Fig. 4. After the thermal treatment procedure the membranes were obviously almost completely insoluble in DMAc at $80^{\circ} \mathrm{C}$ (64-Sh$\mathrm{C}$ and 64-Lo- $\mathrm{Cu}$ ) whereas the non-cured reference membrane (64Ref) readily dissolved completely in less than 20 minutes.

\section{The Fenton test}

The membrane degradation by radical induced oxidation has been identified as one of the major long-term durability limitations of the PA doped PBI based high temperature PEM fuel cells. ${ }^{31-33}$ However, the oxidative resistance of PBI membranes can be dramatically improved by covalent crosslinking, ${ }^{10,13,14,16}$ which also should improve the long-term durability of the PBI based PEM fuel cells.

As shown in Fig. 5, the average rate of weight loss for the noncured reference membrane 48-Ref during the $80 \mathrm{~h}$ of effective Fenton test in the present study was about $0.13 \mathrm{wt}^{\%} \mathrm{~h} \mathrm{~h}^{-1}$. The corresponding result for the cured membrane 48 -Lo-C was about $0.05 \mathrm{wt}^{\%} \% \mathrm{~h}^{-1}$. The rates of weight loss for the cured membrane 48-Lo-C and its non-cured counterpart 48-Ref corresponded well with the rates of weight loss of PBI with an apparent degree of crosslinking of $48 \%$ and its linear counterpart, respectively. ${ }^{14}$ Similar observations were reported for covalently ${ }^{10}$ and ionically crosslinked polymer ${ }^{17}$ as well as PBI variants such as sulfone or hexafluoro modified PBI. ${ }^{19}$

After a weight loss of about $10 \%$, the non-cured reference membrane 48-Ref started to spontaneously disintegrate after about $80 \mathrm{~h}$ in the Fenton solution (photograph A, Fig. 5). In contrast, the cured membrane 48-Lo-C was still in one mechanically stable piece (photograph B, Fig. 5) after $80 \mathrm{~h}$, which further confirmed the improved radical-oxidative resistance of the material.

\section{Phosphoric acid doping}

PA doping was achieved by submerging the membranes in $85 \mathrm{wt}$ $\% \mathrm{H}_{3} \mathrm{PO}_{4}$ at temperatures ranging from room temperature (rt) to $100{ }^{\circ} \mathrm{C}$, as summarized in Table 1 .

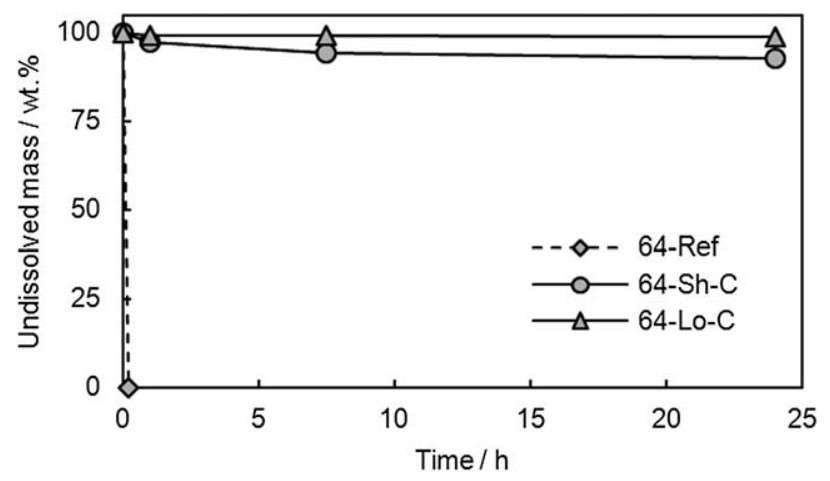

Fig. 4 Membrane solubility in DMAc at $80{ }^{\circ} \mathrm{C}$. The thickness of the membranes was $40 \mu \mathrm{m}$ and the experimental error is about the size of the corresponding markers. 


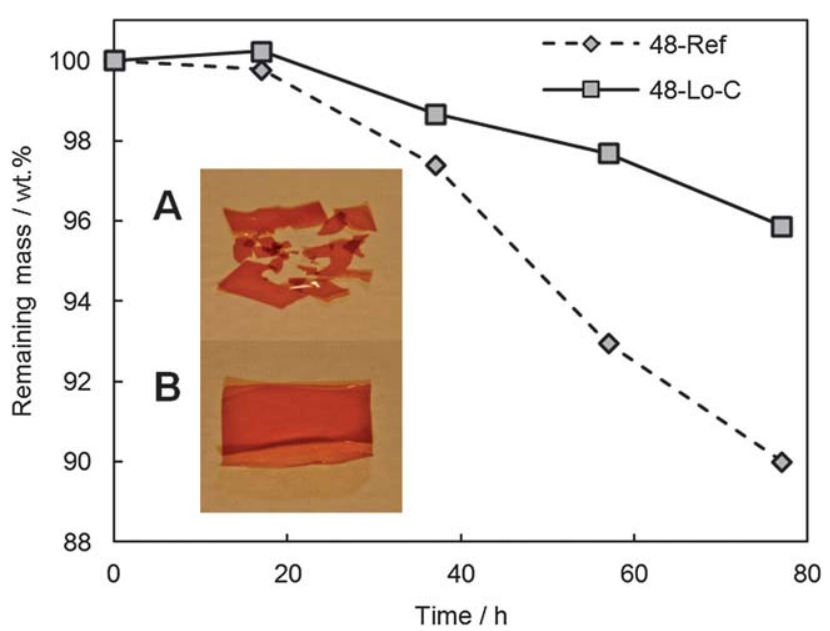

Fig. 5 Remaining membrane mass after certain durations of the Fenton test of the non-cured reference membrane (48-Ref) and of the membrane that had been cured at $350^{\circ} \mathrm{C}$ for $16 \mathrm{~h}$ under argon (48-Lo-C). The insert is photographs of 48-Ref (A) and 48-Lo-C (B) after 80 h Fenton test.

At room temperature a doping level of about 10 was obtained during doping of the non-cured reference membrane 64-Ref, which is in good agreement with the previously reported literature data. ${ }^{34}$ On the other hand, the PA uptake at room temperature of the thermally cured membranes 64-Sh-C and 64-Lo-C was very low and corresponded to acid doping levels of 1.2 and 0.1 , respectively. It further confirms the strong resistance to swelling of the cured membranes, which is also a fundamental characteristic of a covalently crosslinked structure..$^{10,13,14}$ It is well known that elevated doping temperatures are required during doping of crosslinked PBI membranes in order to reach sufficient acid doping levels for any practical use in fuel cells. Analogously, higher PA doping levels could be reached by elevating the doping temperature of the cured membranes in the present study.

During doping at $70^{\circ} \mathrm{C}$, the cured membranes 64-Sh-C and 64Lo-C obtained PA doping levels of 11.8 and 13.5 , respectively. After doping at this temperature the non-cured reference membrane 64-Ref was in a swollen gel-like state that was highly mechanically unstable and could not be handled. By further doping at $100{ }^{\circ} \mathrm{C}$ the non-cured reference membrane 64-Ref was completely dissolved. On the other hand, after doping at $100^{\circ} \mathrm{C}$ in $85 \mathrm{wt} \% \mathrm{H}_{3} \mathrm{PO}_{4}$ for $16 \mathrm{~h}$, the cured membranes 64-Sh-C and 64Lo-C obtained PA doping levels of around 14 and could easily be handled without breaking. The heavily doped cured membranes exhibited good flexibility and sufficient mechanical strength for the MEA preparation. No visual color change was observed in the concentrated $\mathrm{H}_{3} \mathrm{PO}_{4}$ solution during doping, which further illustrates the very limited membrane solubility and indicates

Table 1 PA doping of the non-cured reference membrane (64-Ref) and of the cured membranes (64-Sh-C and 64-Lo-C)

\section{PA doping level}

\begin{tabular}{llcc}
\cline { 2 - 4 } Doping conditions & 64-Ref & 64-Sh-C & 64-Lo-C \\
\hline Rt, 85\% PA & 10.2 & 1.2 & 0.1 \\
$70{ }^{\circ} \mathrm{C}, 85 \% \mathrm{PA}$ & - & 11.8 & 13.5 \\
$100{ }^{\circ} \mathrm{C}, 85 \% \mathrm{PA}$ & Membrane dissolved & 13.6 & 14.1 \\
\hline
\end{tabular}

that PBI changed from a thermoplastic polymer to a thermoset resin during the thermal treatment.

\section{X-Ray diffraction}

Materials of semi-crystalline polymers are most often stiffer, tougher and less soluble than their amorphous counterparts. ${ }^{46}$ For example, membranes of perfluorosulfonic acid (PFSA) such as Nafion ${ }^{\circledast}$ generally require annealing in order to develop the crystalline regions that make them mechanically stable and insoluble in water. ${ }^{35}$

PBI, on the other hand, is known to be more or less amorphous. Generally, the meta configuration of PBI effectively prevents crystallization of the polymer due to its wrinkled linear structure, which results in poor polymer chain packing. ${ }^{23,36}$ This might also be the sole reason for the relatively good solubility of $m$-PBI in a limited number of highly polar aprotic organic solvents. ${ }^{5}$

The morphology of polybenzimidazoles can be modified by careful tuning of the reaction parameters during the polycondensation or by tailoring the structure of the polymer backbone. ${ }^{36}$ For example, Scariah et al..$^{37}$ synthesized a set of parapolybenzimidazole structure analogues containing flexibilizing spacers in the polymer backbone. The linear structure of the polymer dramatically affected the degree of crystallinity and thus its solubility. Employing a heat treatment procedure at temperatures of up to $350{ }^{\circ} \mathrm{C}$ in combination with different aromatic reagents under pressure, Conciatori et al. ${ }^{38}$ patented a process for increasing the crystallinity of various polybenzimidazole fibres. Furthermore, Arrieta et al..$^{39}$ heat treated PBI, Kevlar ${ }^{\circledR}$ and their blends at temperatures of up to $320^{\circ} \mathrm{C}$ for $1-15$ days and the $\mathrm{X}$ ray diffraction measurements showed a gradual increase of the crystallinity of the polymer blend during the heat treatment.

The wide angle X-ray diffractograms (WAXDs) of the PBI membranes in the present study and their PA doped counterparts are shown in Fig. 6A. As previously reported, ${ }^{5,21}$ the pristine PBI membrane (64-Ref) was found to be fully amorphous. However, after a short heat treatment at $350{ }^{\circ} \mathrm{C}$ under inert atmosphere (64-Sh-C) a broad reflection centred around $18^{\circ}$ was developed confirming an increase of the structural order within the membrane. For comparison, a similar broad reflection was reported for PBI precipitates that had been treated at temperatures up to $350{ }^{\circ} \mathrm{C} .{ }^{36}$

The choice of membrane casting procedure and the nature of the solvent are also known to affect the morphology of the obtained PA doped membrane. For example, PBI membranes cast from mixtures of trifluoroacetic acid (TFA) and PA are more crystalline than acid imbibed PBI membranes that have been solution cast from DMAc. ${ }^{40}$ Furthermore, ABPBI membranes prepared by direct casting from methanesulfonic acid (MSA) and PA are more crystalline than the ABPBI membranes prepared by casting from MSA followed by PA imbibing. ${ }^{41}$ The relatively high degree of crystallinity of the TFA cast membranes was reported to result in a PA doped membrane that was more rubbery and soft than the conventional solution cast and acid imbibed membranes. The degree of crystallinity of the PA doped membranes could be further increased by heat treatment. Additionally, the membrane of higher crystallinity exhibited higher proton conductivity. It was suggested that the 

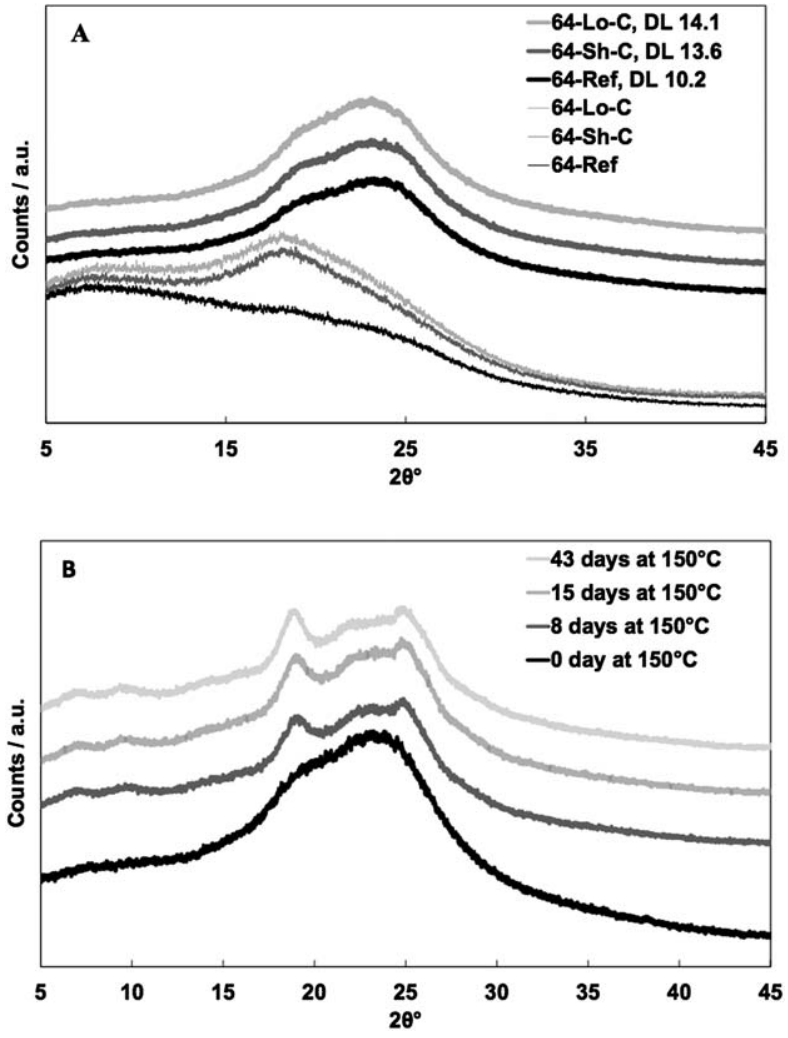

Fig. 6 (A) X-Ray diffractograms of the non-cured reference membrane (64-Ref) and the cured membranes (64-Sh-C and 64-Lo-C) before and after acid doping. The corresponding PA doping levels (DLs) are indicated in the figure. (B) X-Ray diffractograms of the PA doped non-cured reference membrane (44-Ref) (DL 12.5) after anhydrous thermal aging at $150{ }^{\circ} \mathrm{C}$ for up to 43 days.

PA was forced into the amorphous regions, thus creating highly proton conducting pathways through the membrane crosssection. ${ }^{42}$

ABPBI, the most simple structure analogue within the polybenzimidazole family, is known to exhibit a rather high degree of crystallinity. The degree of crystallinity can be further increased by heat treatment or by stretching the material in order to enhance the polymer chain orientation. ${ }^{43}$ Cho et al. ${ }^{44}$ showed that ABPBI membranes cast from $\mathrm{EtOH} / \mathrm{NaOH}$ exhibited a crystalline uniplanar structure in which the aromatic rings are aligned parallel to the film surface. However, during doping in PA most of the crystalline order in the membrane was lost due to the extensive volume swelling and the concomitant polymer chain separation.

This was also confirmed in the present study. After PA doping all the membranes were apparently morphologically equal regardless of their thermal history. However, the acid doping levels varied between 10.2 and 14.1 depending on the thermal history of the membranes and the doping conditions. The diffraction data of all the acid doped membranes showed a broad reflection centred around $23^{\circ}$, which corresponded well with the previously reported X-ray diffraction data of PA doped PBI membranes with a doping level of $4.8 .^{42}$

Under high temperature PEM fuel cell operating conditions the PA doped membrane is naturally subjected to temperatures in the $100-200{ }^{\circ} \mathrm{C}$ range for extended periods of time. It is thus of interest to study the effect of high temperatures on the morphology of PA doped PBI membranes. X-Ray diffractograms of the non-cured PA doped reference membrane (64-Ref) were therefore recorded after anhydrous aging at $150{ }^{\circ} \mathrm{C}$ for up to about 6 weeks, as shown in Fig. 6B. As also observed by Savinell et al. ${ }^{40}$ heat treatment of the PA doped PBI membrane resulted in a gradual increase of its degree of crystallinity. This was illustrated by the development of two relatively sharp reflections at $18.5^{\circ}$ and at $23.5^{\circ}$ during thermal aging. For comparison, after PA impregnation of polybenzimidazoles containing alkyl spacers it was found that crystalline polymeric salts were developed only when an even number of $-\mathrm{CH}_{2}$ - spacing groups separated the benzimidazole moieties. The X-ray diffractograms of the crystalline polymeric salt showed strong and relatively sharp reflections centered around $19.6^{\circ}$ and $24.6^{\circ},{ }^{45}$ which is in good agreement with the diffraction pattern of the thermally aged membrane in the present study.

\section{Mechanical strength}

In order to study the correlation between the thermal history of PBI and the mechanical properties of the membranes after PA doping, stress-strain curves were recorded at room temperature and atmospheric humidity, as shown in Fig. 7. Generally, one can see that the $T_{\mathrm{g}}$ of the membranes after acid doping were significantly lower than that of pristine PBI $\left(T_{\mathrm{g}}=425-436{ }^{\circ} \mathrm{C}\right)$, which has a Young's modulus of as high as $6 \mathrm{GPa}$ at room temperature. The linear average molecular weight of PBI was also varied from 23 to $44 \mathrm{kDa}$ since the mechanical properties of PA doped PBI membranes are known to be highly dependent on the linear average molecular weight of the polymer. ${ }^{12}$ The mechanical data are also summarized in Table 2.

The PA doped membranes based on PBI with a linear average molecular weight of $23 \mathrm{kDa}$ that had been cured at $350{ }^{\circ} \mathrm{C}$ under argon for different durations were obviously tougher compared with their non-cured counterpart of similar linear average molecular weight. For example, even though the PA doping level of the cured membrane 23-Lo-C was about 20\% higher compared with that of its non-cured counterpart (23-Ref) the yield stress was almost twice as high. Furthermore, the elongation at break gradually decreased with increasing curing time from about $140 \%$ for the non-cured reference membrane 23 -Ref to about $80 \%$ for the membrane that had been cured for $16 \mathrm{~h}$ (23Lo-C), indicating the reduced polymer chain mobility. Additionally, the resistance to plastic deformation of the PA doped 23-Lo-C membrane was considerably higher than that of its noncured counterpart (23-Ref) as indicated by a steeper slope of the stress-strain curve beyond the yield point.

Despite the higher PA doping level, the Young's modulus of the cured membrane 23-Lo-C was nearly 3 times higher than that of its non-cured counterpart (23-Ref). The mechanical toughening after the thermally induced curing of the membranes having an intermediate linear average molecular weight of 44 $\mathrm{kDa}$ was not as obvious. However, as expected ${ }^{\mathbf{1 2}}$ the mechanical properties in terms of the engineering tensile stress at break as well as the Young's modulus of the non-cured reference membrane were considerably improved when the initial linear average molecular weight of PBI was increased from $23 \mathrm{kDa}$ 


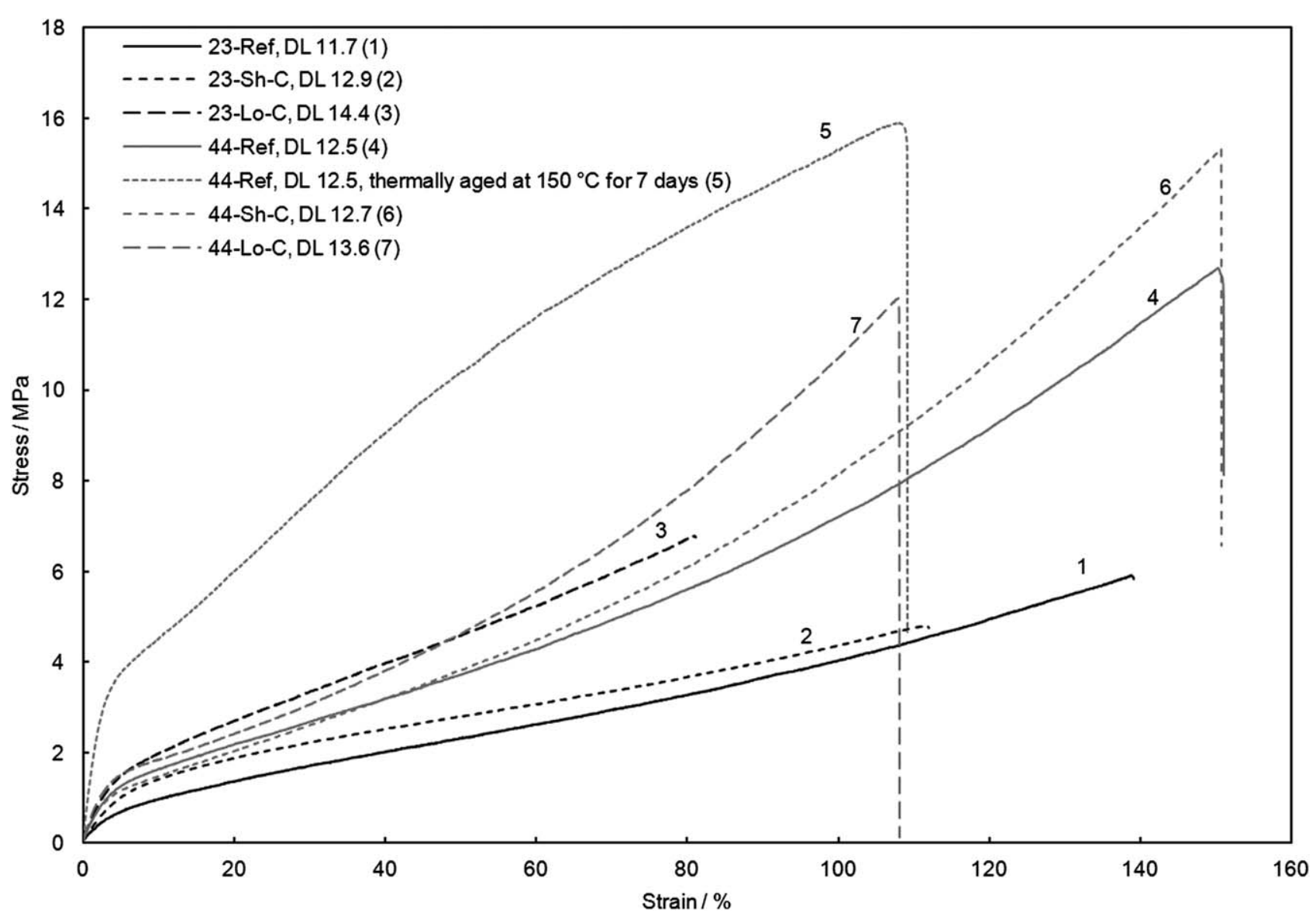

Fig. 7 Representative stress-strain curves at room temperature and atmospheric humidity of membranes with different thermal history and initial linear average molecular weights of $23 \mathrm{kDa}$ (23-Ref, 23-Sh-C and 23-Lo-C) and $44 \mathrm{kDa}$ (44-Ref, 44-Sh-C and 44-Lo-C). The corresponding acid doping levels (DLs) are indicated in the figure. A representative stress-strain curve of the PA doped (44-Ref) membrane that had been thermally aged at $150{ }^{\circ} \mathrm{C}$ for 7 days is also shown. The membrane thicknesses were about $80 \mu \mathrm{m}$.

(23-Ref) to $44 \mathrm{kDa}$ (44-Ref). For example, even though the PA doping level was slightly higher the Young's modulus was nearly doubled when the linear average molecular weight was increased from $23 \mathrm{kDa}$ (23-Ref) to $44 \mathrm{kDa}$ (44-Ref). The Young's modulus of the cured membrane $23-\mathrm{Lo}-\mathrm{C}$ was similar to that of the noncured reference membrane with a higher initial average molecular weight of $44 \mathrm{kDa}$ (44-Ref). On the other hand, the Young's modulus of the $44 \mathrm{kDa}$ linear average molecular weight noncured reference membrane (44-Ref) was considerably lower than that of the membrane with a similar linear average molecular weight but lower acid doping level, ${ }^{14}$ which further illustrates the strong plasticizing effect of PA.

The cured membranes that were prepared from PBI with a linear average molecular weight of $44 \mathrm{kDa}$ (44-Sh-C and 44-LoC) showed lower elongation at break and a steeper slope of the stress-strain curve beyond the yield point than those of their non-cured counterpart (44-Ref). It indicates increased resistance to plastic deformation and increasing rigidity in the rubbery region. Furthermore, the Young's modulus of the cured membrane 44-Lo-C was slightly higher than that of its non-cured

Table 2 Summary of the mechanical data at room temperature. The membrane types and the corresponding PA doping levels are indicated. The reported values are the average values of at least 5 samples and the errors represent the corresponding standard deviations

\begin{tabular}{|c|c|c|c|}
\hline Membrane type & $\begin{array}{l}\text { Young's } \\
\text { modulus/MPa }\end{array}$ & $\begin{array}{l}\text { Engineering tensile } \\
\text { stress at break/MPa }\end{array}$ & $\begin{array}{l}\text { Elongation at } \\
\text { break } \% \%\end{array}$ \\
\hline 23-Ref, DL 11.7 & $10.9 \pm 0.9$ & $5.7 \pm 0.4$ & $136 \pm 11$ \\
\hline 23-Lo-C, DL 14.4 & $27.9 \pm 1.4$ & $5.7 \pm 1.6$ & $67 \pm 21$ \\
\hline 44-Ref, DL 12.5 & $26.3 \pm 1.5$ & $13.3 \pm 1.1$ & $155 \pm 7$ \\
\hline 44-Sh-C, DL 12.7 & $27.6 \pm 3.2$ & $14.4 \pm 1.4$ & $144 \pm 8$ \\
\hline 44-Lo-C, DL 13.6 & $37.1 \pm 2.7$ & $12.1 \pm 1.0$ & $108 \pm 5$ \\
\hline
\end{tabular}


counterpart (44-Ref), even though the PA doping level was about $9 \%$ higher.

\section{Proton conductivity}

As shown in Fig. 8, the anhydrous proton conductivity of the PA doped cured membranes (64-Sh-C and 64-Lo-C) was somewhat higher than that of the PA doped non-cured reference membrane 64-Ref, apparently due to the slightly higher PA contents. ${ }^{47}$ At $150{ }^{\circ} \mathrm{C}$ it varied between 0.04 and $0.06 \mathrm{~S} \mathrm{~cm}^{-1}$ depending on the acid doping level of the membrane. The conductivity data were in good agreement with that of covalently ${ }^{10,13,14}$ or ionically ${ }^{18}$ crosslinked PBI based membranes or PBI structure analogue based membranes ${ }^{18}$ of similar doping levels.

The proton conductivity of PA solutions is strongly dependent on the water content. For example, at $20^{\circ} \mathrm{C}$ the conductivity of $100 \%$ and $45 \%$ PA was reported to differ by about an order of magnitude. It was increased from $0.025 \mathrm{~S} \mathrm{~cm}^{-1}$ to $0.22 \mathrm{~S} \mathrm{~cm}^{-1}$ when the $\mathrm{H}_{3} \mathrm{PO}_{4}$ concentration was reduced from $100 \%$ to $45 \%{ }^{48}$ At temperatures around $170{ }^{\circ} \mathrm{C}$ and without active humidification, $\mathrm{H}_{3} \mathrm{PO}_{4}$ dehydrates to pyrophosphoric acid or higher phosphoric acid oligomers that are less proton conducting than orthophosphoric acid, ${ }^{49}$ which also affects the mechanical properties of the membrane as illustrated in Fig. 7. Hence, the conductivity at temperatures at or above $170{ }^{\circ} \mathrm{C}$ should be strongly dependent on the water content of the membrane. The phosphoric acid dehydration was illustrated in the present study by a proton conductivity decay at temperatures above $160{ }^{\circ} \mathrm{C}$. A similar effect has also been observed for PA doped PBI membranes of low doping levels cast from TFA/ $/ \mathrm{PA}^{47}$ as well as for PA doped PBI with very high acid doping levels prepared according to the sol-gel methodology. ${ }^{11}$

\section{Fuel cell test}

Continuous steady state operation at a constant load in the 150 $160{ }^{\circ} \mathrm{C}$ temperature range is a mild mode for PA doped PBI based fuel cells. The complete absence of liquid water minimizes the risk for the PA washout, which is of critical concern for the long-term durability of the cells since it would gradually reduce

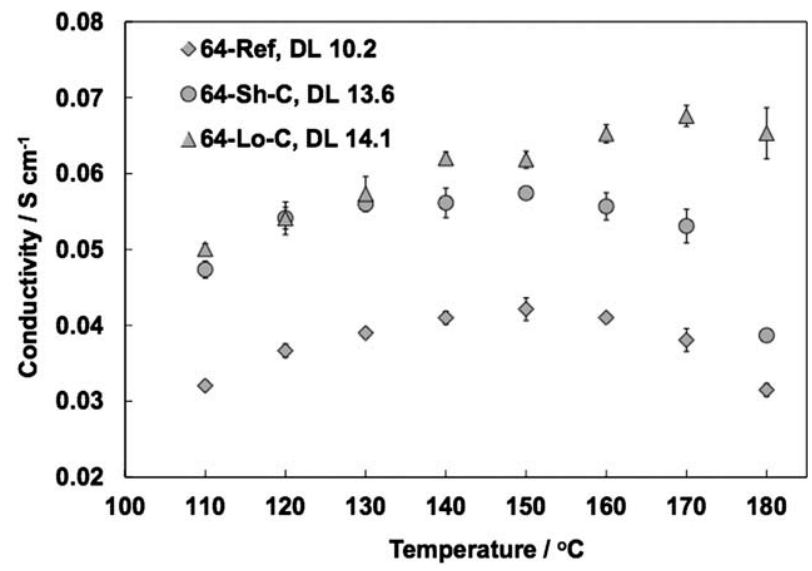

Fig. 8 Anhydrous proton conductivity of the PA doped non-cured reference membrane (64-Ref) and of the cured membranes (64-Sh-C and 64-Lo-C). The corresponding doping levels (DLs) are indicated in the figure. the membrane conductivity. ${ }^{50}$ The constant temperature also minimizes the stresses connected to thermal expansion or contraction of the different layers in the MEA and therefore the deterioration of the membrane electrode interface. Furthermore, the cell voltage during steady state operation is considerably lower than the OCV which minimizes the oxidation rate of the carbon based catalyst support materials as well as the dissolution of the noble metals, which is very much potential dependent. The catalyst degradation rate can thus be expected to be considerably reduced if the fuel cell idling can be circumvented. ${ }^{51}$ In other words, the major cause of failure of a PBI based fuel cell in the steady state operation mode is most likely connected to the membrane degradation.

Polarization curves of the MEA based on the cured membrane 48-Lo-C were recorded after continuous fuel cell operation at a constant current load of $600 \mathrm{~mA} \mathrm{~cm}^{-2}$ for up to about $1800 \mathrm{~h}$, as shown in Fig. 9. The OCV was slightly decreased during the first $1800 \mathrm{~h}$ of operation from $818 \mathrm{mV}$ to $791 \mathrm{mV}$, which was most likely connected to the gradually increased gas permeability of the membrane. In the higher current density range the ageing of the MEA was illustrated by a steeper slope of the polarization curve in the linear region. The increased ohmic resistance over time could eventually be explained by the leakage of PA through the steam distillation mechanism. It has previously been reported to be one of the major degradation mechanisms of PA doped PBI based fuel cells, especially during high load operation when the water formation rate is high. ${ }^{50}$ The gradual decay of the fuel cell performance over time was also illustrated by a reduced power density, especially in the high current density range.

Several long-term durability investigations of PA doped PBI or PBI structure analogue based high temperature PEM fuel cells operated at a constant load or in load cycling mode have been published during the past decade. ${ }^{11,50,52-57}$ However, during the steady state tests the cells were generally operated at a rather low current load. For example, BASF-PEMEAS ${ }^{54}$ has demonstrated a lifetime exceeding 20000 hours at $160{ }^{\circ} \mathrm{C}$ and at a constant current load of $200 \mathrm{~mA} \mathrm{~cm}^{-2}$. The average cell voltage decay rate during operation was estimated to be about $5-6 \mu \mathrm{V} \mathrm{h}^{-1}$. Similar

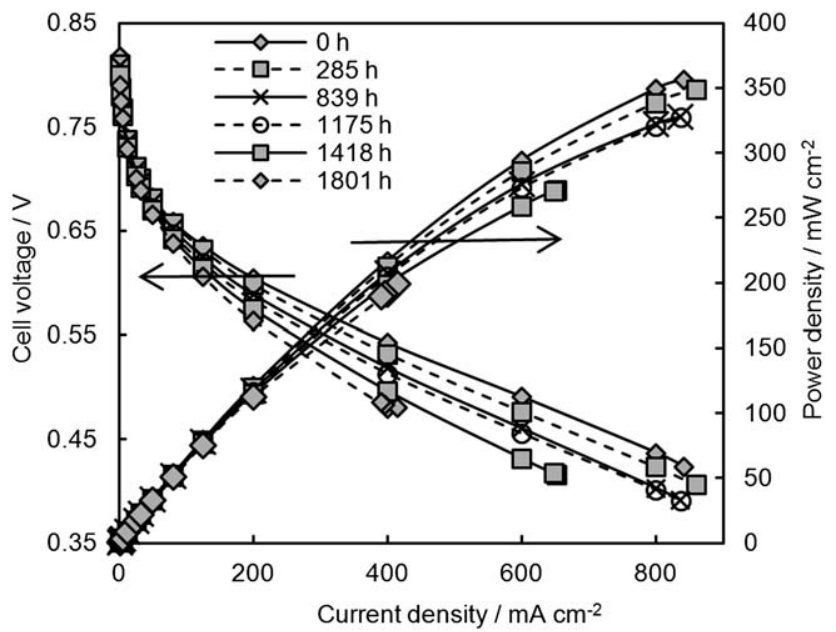

Fig. 9 Polarization curves of the MEA based on the membrane that had been cured at $350{ }^{\circ} \mathrm{C}$ for $16 \mathrm{~h}$ under argon (48-Lo-C) prior to the acid doping. The polarization curves were recorded after fuel cell operation at a constant load of $600 \mathrm{~mA} \mathrm{~cm}{ }^{-2}$ for up to $1801 \mathrm{~h}$. 
measurements were made by $\mathrm{Yu}$ et $a .^{50}$ under steady-state conditions, showing an average voltage decay rate of 4.9-6.3 $\mu \mathrm{V}$ $\mathrm{h}^{-1}$ at $160{ }^{\circ} \mathrm{C}$. The water formation rate at the cathode naturally increases with the current density which also dramatically increased the PA loss, especially at high operating temperatures in the $180-190{ }^{\circ} \mathrm{C}$ range. The effect of operating temperature was further illustrated by the reduction of the demonstrated lifetime of 5000-20 $000 \mathrm{~h}$ to a few hundreds of hours when the operating temperature was increased from $150-160{ }^{\circ} \mathrm{C}$ to $180-200{ }^{\circ} \mathrm{C}^{58}$ This was apparently due to the membrane failure because the eventual death of the cell was accompanied by a sudden increase of the gas permeability.

The long lifetimes or the very low voltage decay rates reported for the PA doped PBI based fuel cells were typically achieved during continuous operation at $120-160{ }^{\circ} \mathrm{C}$ and at rather low current loads of typically $200 \mathrm{~mA} \mathrm{~cm}$. At higher current densities much higher voltage decay rates have been reported. For example, during steady state operation at a constant current load of $400 \mathrm{~mA} \mathrm{~cm}^{-2}$ at $160{ }^{\circ} \mathrm{C}$ for $1150 \mathrm{~h}$ the average cell voltage decay rate was about $43 \mu \mathrm{V} \mathrm{h}^{-1} \cdot{ }^{11}$ Furthermore, Li and Scott ${ }^{59}$ operated a PTFE reinforced PA doped PBI based MEA in start/ stop fuel cell mode at a constant load of $700 \mathrm{~mA} \mathrm{~cm}^{-2}$, showing an obvious gradual decay of the cell voltage during $50 \mathrm{~h}$.

The low cell voltage decay rate during continuous fuel cell operation at $160{ }^{\circ} \mathrm{C}$ at a low current load of $200 \mathrm{~mA} \mathrm{~cm}{ }^{-2}$ was confirmed in the present study, as shown in Fig. 10. Under these conditions the cell based on the non-cured reference membrane 48-Ref showed an average voltage decay rate of about $5-6 \mu \mathrm{V} \mathrm{h}^{-1}$ during about $2000 \mathrm{~h}$ of operation. The initial cell voltage of the MEA based on the cured membrane 48-Lo-C operating at $200 \mathrm{~mA} \mathrm{~cm}^{-2}(0.60 \mathrm{~V})$ was practically identical with that of the MEA based on its non-cured counterpart (0.61 V). However, a current load malfunction of the cell based on the cured membrane 48-Lo-C occurred after about $100 \mathrm{~h}$ of operation that resulted in load cycling mode in the $100-1050 \mathrm{~h}$ range. During

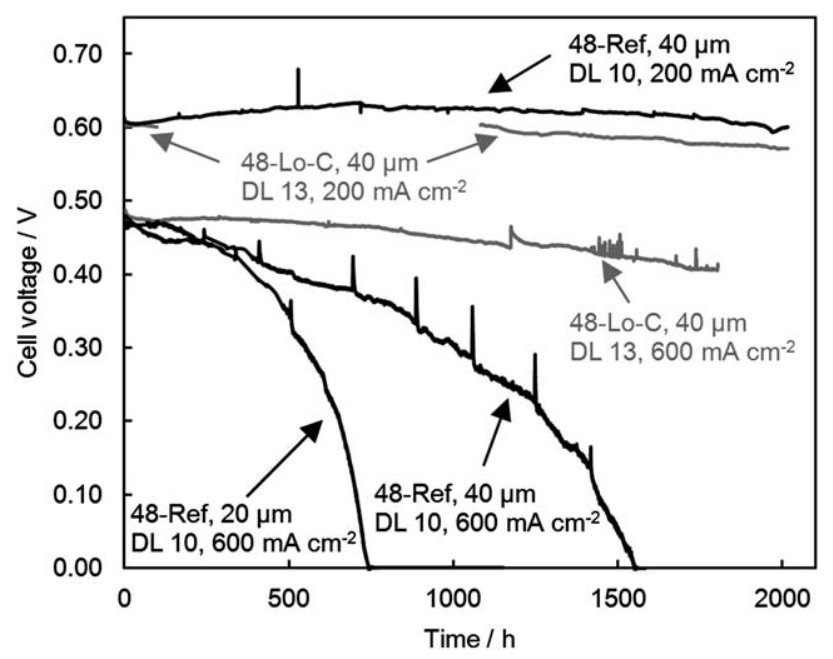

Fig. 10 Fuel cell voltages as a function of time for the MEAs based on non-cured PBI (48-Ref, black lines) and PBI that had been cured at $350{ }^{\circ} \mathrm{C}$ for $16 \mathrm{~h}$ under argon (48-Lo-C, grey lines) prior to the acid doping. The cells were operated at a current load of $200 \mathrm{~mA} \mathrm{~cm}$ or $600 \mathrm{~mA} \mathrm{~cm}{ }^{-2}$. The corresponding membrane thicknesses and doping levels (DLs) are indicated in the figure. this period the current density varied between 0 and $200 \mathrm{~mA} \mathrm{~cm}^{-2}$ which implies that the cell voltage varied between OCV and about $0.6 \mathrm{~V}$. This type of load cycling is well known to enhance the degradation rate of the MEA, ${ }^{50,54}$ which was illustrated in the present study by a slightly higher average cell voltage decay rate of $13 \mu \mathrm{V} \mathrm{h}^{-1}$ during about $2000 \mathrm{~h}$ operation.

At a constant current load of $600 \mathrm{~mA} \mathrm{~cm}^{-2}$ the MEA based on the $20 \mu \mathrm{m}$ thick non-cured reference membrane (48-Ref) showed an average cell voltage decay rate of about $630 \mu \mathrm{V} \mathrm{h}^{-1}$. When the membrane thickness of the non-cured reference membrane (48Ref) was doubled to $40 \mu \mathrm{m}$ the average cell voltage decay rate was reduced to about $308 \mu \mathrm{V} \mathrm{h}^{-1}$. The cell voltages of the two cells reached zero after about $750 \mathrm{~h}$ and $1550 \mathrm{~h}$, respectively, which indicate a complete membrane failure. Obviously, by reducing the thickness of the membrane by $50 \%$ the average cell voltage decay rate was doubled, which further confirms that the cell voltage decay during operation at high current load is strongly connected to the membrane degradation. The MEA based on the PBI membrane that had been cured at $350{ }^{\circ} \mathrm{C}$ for 16 $\mathrm{h}$ under argon prior to doping in $85 \mathrm{wt} \% \mathrm{H}_{3} \mathrm{PO}_{4}$ at $100{ }^{\circ} \mathrm{C}(48-$ Lo-C), on the other hand, showed a considerably lower average cell voltage decay rate of $43 \mu \mathrm{V} \mathrm{h}^{-1}$. After $1800 \mathrm{~h}$ of continuous operation at a current load of $600 \mathrm{~mA} \mathrm{~cm}^{-2}$, the cell voltage had decreased from about $0.49 \mathrm{~V}$ to $0.41 \mathrm{~V}$.

\section{Conclusions}

The thermochemical properties of PBI were investigated using ATR-FTIR in combination with TGA/DTA. PBI was found to irreversibly cure during heat treatment at $350{ }^{\circ} \mathrm{C}$ under argon atmosphere. The change from a thermoplastic polymer to a thermoset resin was illustrated by a dramatically reduced solubility and improved radical-oxidative stability. The thermal treatment also affected the structural order within the membrane as confirmed by X-ray diffraction. After PA doping, all membranes were apparently morphologically equal. After PA doping the cured PBI membranes were considerably tougher than their non-cured counterparts even though the acid doping levels were higher. During continuous fuel cell operation at 160 ${ }^{\circ} \mathrm{C}$ for $2000 \mathrm{~h}$ at a low current load of $200 \mathrm{~mA} \mathrm{~cm}^{-2}$ the average cell voltage decay rate of the MEA based on the non-cured membrane was 5-6 $\mu \mathrm{V} \mathrm{h}^{-1}$. Under similar operating conditions but at a considerably higher current load of $600 \mathrm{~mA} \mathrm{~cm}^{-2}$ the average cell voltage decay rates of the MEAs based on the noncured membrane and the cured membrane were $308 \mu \mathrm{V} \mathrm{h}^{-1}$ and $43 \mu \mathrm{V} \mathrm{h}^{-1}$, respectively. The results confirm that the long-term durability of PBI based high temperature PEM fuel cells is highly dependent on the membrane characteristics, especially at high current loads, and can be obviously improved by introducing a thermal treatment step of the membrane before acid doping and MEA manufacturing.

\section{Acknowledgements}

Danish Power Systems ApS is gratefully acknowledged for supplying materials and for preparing the MEAs. Funding of this work is acknowledged from the Danish ForskEL programme, the Danish National Research Foundation and the Danish Energy Agency. 


\section{References}

1 J. S. Wainright, J. T. Wang, D. Weng, R. F. Savinell and M. Litt, J. Electrochem. Soc., 1995, 142, L121-L123.

2 Q. Li, J. O. Jensen, R. F. Savinell and N. J. Bjerrum, Prog. Polym. Sci., 2009, 34, 449-477.

3 O. Paschos, J. Kunze, U. Stimming and F. Maglia, J. Phys.: Condens. Matter, (2011), DOI: 10.1088/0953-8984/23/23/234110 (26 pp).

4 T. S. Chung, J. Macromol. Sci., Rev. Macromol. Chem. Phys., 1997, C37, 277-301.

5 H. Vogel and C. S. Marvel, J. Polym. Sci., 1961, 50, 511.

6 E. W. Neuse, Adv. Polym. Sci., 1982, 47, 1-42.

7 Y. Iwakura, Y. Imai and K. Uno, J. Polym. Sci., Part A: Gen. Pap., 1964, 2, 2605-2615.

8 E. W. Choe and D. D. Choe, in Polymeric Materials Encyclopedia, ed J. C. Salamone, CRC Press, New York, 1996, vol. 7, pp. 5619-5638.

9 J. S. Wainright, M. H. Litt and R. F. Savinell, in Handbook of Fuel Cells: Fundamentals, Technology and Applications, ed. W. Vielstich, A. Lamm and H. A. Gasteiger, John Wiley \& Sons Ltd, Chichester, 2003, vol. 3, pp. 436-446.

10 Q. Li, C. Pan, J. O. Jensen, P. Noyé and N. J. Bjerrum, Chem. Mater., $2007,19,350-352$.

11 L. X. Xiao, H. F. Zhang, E. Scanlon, L. S. Ramanathan, E. W. Choe, D. Rogers, T. Apple and B. C. Benicewicz, Chem. Mater., 2005, 17, $5328-5333$

12 R. H. He, Q. Li, A. Bach, J. O. Jensen and N. J. Bjerrum, J. Membr. Sci., 2006, 277, 38-45.

13 P. Noyé, Q. Li, C. Pan and N. J. Bjerrum, Polym. Adv. Technol., 2008, 19, 1270-1275.

14 D. Aili, Q. Li, E. Christensen, J. O. Jensen and N. J. Bjerrum, Polym. Int., 2011, 60, 1201-1207.

15 S. Yu, H. Zhang, L. Xiao, E. W. Choe and B. C. Benicewicz, Fuel Cells, 2009, 9, 318-324.

16 M. Han, G. Zhang, Z. Liu, S. Wang, M. Li, J. Zhu, H. Li, Y. Zhang, C. M. Lew and H. Na, J. Mater. Chem., 2011, 21, 2187-2193.

17 J. Kerres, F. Schönberger, A. Chromik, T. Häring, Q. Li, J. O. Jensen, C. Pan, P. Noyé and N. J. Bjerrum, Fuel Cells, 2008, 8, 175-187.

18 Q. Li, J. O. Jensen, C. Pan, V. Bandur, M. S. Nilsson, F. Schönberger, A. Chromik, M. Hein, T. Häring, J. Kerres and N. J. Bjerrum, Fuel Cells, 2008, 8, 188-199.

19 Q. Li, H. C. Rudbeck, A. Chromik, J. O. Jensen, C. Pan, T. Steenberg, M. Calverley, N. J. Bjerrum and J. Kerres, J. Membr. Sci., 2010, 347, 260-270

20 D. Aili, M. K. Hansen, C. Pan, Q. Li, E. Christensen, J. O. Jensen and N. J. Bjerrum, Int. J. Hydrogen Energy, 2011, 36, 6985-6993.

21 H. H. Levine, in Encyclopedia of Polymer Science and Technology, ed N. M. Bikales, J. Conrad, A. Ruks and J. Perlman, Interscience New York, 1969, vol. 11, pp. 188-232.

22 J. K. Gillham, Science, 1963, 139, 494-495.

23 V. I. Kasatochkin, V. V. Korshak, V. V. Kurashev, Z. S. Smutkina, T. M. Frunze and T. M. Khrenkova, Dokl. Chem. Technol., 1964, 159, 843-846.

$24 \mathrm{~W}$. F. Hwang, D. R. Wiff, C. Verschoore, G. E. Price, T. E. Helminiak and W. W. Adams, Polym. Eng. Sci., 1983, 23, 784-788.

25 P. Musto, F. E. Karasz and W. J. MacKnight, Polymer, 1993, 34, $2934-2945$

26 G. P. Shulman and W. Lochte, J. Macromol. Sci., Part A: Pure Appl.Chem., 1967, 1, 413-428.

27 R. A. Gaudiana and R. T. Conley, J. Polym. Sci., Part B: Polym. Lett., 1969, 7, 793-801.
28 R. T. Conley, J. J. Kane and S. Ghosh, Mechanism of Thermal Oxidation of the Benzimidazole System, Technical Report AFMLTR-71-219, Department of Chemistry, Wright State University, Dayton, 1971

29 C. A. Linkous, Int. J. Hydrogen Energy, 1993, 18, 641-646.

30 A. Buckley, D. Stuetz and G. A. Serad, in Encyclopedia of Polymer Science and Engineering, ed. J. I. Kroschwitz, Wiley, New York, 1987, vol. 11, pp. 572-601.

31 J. H. Liao, Q. F. Li, H. C. Rudbeck, J. O. Jensen, A. Chromik, N. J. Bjerrum, J. Kerres and W. Xing, Fuel Cells, 2011, 11, 745-755.

32 Z. Chang, H. Pu, D. Wan, L. Liu, J. Yuan and Z. Yang, Polym. Degrad. Stab., 2009, 94, 1206-1212.

33 A. D. Modestov, M. R. Tarasevich, V. Y. Filimonov and N. M. Zagudaeva, Electrochim. Acta, 2009, 54, 7121-7127.

34 Q. Li, R. H. He, R. W. Berg, H. A. Hjuler and N. J. Bjerrum, Solid State Ionics, 2004, 168, 177-185.

35 G. Gebel, P. Aldebert and M. Pineri, Macromolecules, 1987, 20, 14251428 .

36 S.-I. Kohama, J. Gong, K. Kimura, S. Yamazaki, T. Uchida, K. Shimamura and K. Kimura, Polymer, 2008, 49, 1783-1791.

37 K. J. Scariah, V. N. Krishnamurthy, K. V. C. Rao and M. Srinivasan, J. Polym. Sci., Part A: Polym. Chem., 1987, 25, 2675-2687.

38 A. B. Conciatori, E. C. Chenevey, H. D. Noether, M. Dunay, US Pat., 3495931, 1970.

39 C. Arrieta, E. David, P. Dolez and T. Vu-Khanh, Polym. Compos., 2011, 32, 362-367.

40 R. F. Savinell, J. S. Wainright and M. Litt, Proc. - Electrochem. Soc., 1999, 98-27, 81-87.

41 J. A. Asensio, S. Borros and P. Gomez-Romero, J. Membr. Sci., 2004, 241, 89-93.

42 M. Litt, R. Ameri, Y. Wang, R. Savinell and J. Wainright, in Solid StateIonics V, ed. G. A. Nazri, C. Julien and A. Rougier, Materials Research Society, Warrendale, 1999, vol. 548, pp. 313-323.

43 W. F. Hwang, D. R. Wiff, C. L. Benner and T. E. Helminiak, J. Macromol. Sci., Part B: Phys., 1983, 22, 231-257.

44 J. Cho, J. Blackwell, S. N. Chvalun, M. Litt and Y. Wang, J. Polym. Sci., Part B: Polym. Phys., 2004, 42, 2576-2585.

45 S. M. Aharoni, J. Appl. Polym. Sci., 1982, 27, 989-995.

46 M. P. Stevens, Polymer Chemistry-An Introduction, Oxford University Press, New York, 3rd edn, 1999, pp. 79-83.

47 Y. L. Ma, J. S. Wainright, M. H. Litt and R. F. Savinell, J. Electrochem. Soc., 2004, 151, A8-A16.

48 R. H. He, Q. Li, G. Xiao and N. J. Bjerrum, J. Membr. Sci., 2003, 226, 169-184.

49 A. Schechter and R. F. Savinell, Solid State Ionics, 2002, 147, 181187.

50 S. Yu, L. Xiao and B. C. Benicewicz, Fuel Cells, 2008, 8, 165-174.

51 Z. Qi and S. Buelte, J. Power Sources, 2006, 161, 1126-1132.

52 C. Wannek, B. Kohnen, H. F. Oetien, H. Lippert and J. Mergel, Fuel Cells, 2008, 8, 87-95.

53 T. J. Schmidt and J. Baurmeister, ECS Trans., 2006, 3, 861-869.

54 T. J. Schmidt and J. Baurmeister, J. Power Sources, 2008, 176, 428434.

55 J. A. Mader and B. C. Benicewicz, Fuel Cells, 2011, 11, 222-237.

56 J. A. Mader and B. C. Benicewicz, Macromolecules, 2010, 43, 67066715.

57 F. J. Pinar, P. Cañizares, M. A. Rodrigo, D. Úbeda and J. Lobato, J. Power Sources, 2011, 196, 4306-4313.

58 Q. Li and J. O. Jensen, in Membranes for Energy Conversion, ed. K. V. Peinemann and S. P. Nunes, WILEY-VCH Verlag GmbH \& Co. KGaA, Weinheim, 2008, vol. 2, pp. 61-96.

$59 \mathrm{M} . \mathrm{Li}$ and K. Scott, Electrochim. Acta, 2010, 55, 2123-2128. 